\title{
Autolysis of Pichia pastoris induced by cold
}

\author{
Yaneth Bartolo-Aguilar', Luc Dendooven', Cipriano Chávez-Cabrera', Luis B. Flores-Cotera', \\ María E. Hidalgo-Lara', Lourdes Villa-Tanaca ${ }^{2}$ and Rodolfo Marsch ${ }^{1^{*}}$ (I)
}

\begin{abstract}
The production of recombinant biopharmaceutical proteins is a multi-billion dollar market. Protein recovery represents a major part of the production costs. Pichia pastoris is one of the microbial systems most used for the production of heterologous proteins. The use of a cold-induced promoter to express lytic enzymes in the yeast after the growth stage could reduce protein recovery costs. This study shows that a cold-shock can be applied to induce lysis of the yeast cells. A strain of P. pastoris was constructed in which the endogenous eng gene encoding a putative endo- $\beta-1,3-$ glucanase was overexpressed using the cold-shock induced promoter of the ccta gene from Saccharomyces cerevisiae. In the transgenic P. pastoris, the expression of eng increased 3.6-fold after chilling the cells from 30 to $4{ }^{\circ} \mathrm{C}$ (cold-shock stage) followed by incubation for $6 \mathrm{~h}$ (eng expression stage). The culture was heated to $30^{\circ} \mathrm{C}$ for $6 \mathrm{~h}$ (ENG synthesis stage) and kept at $37^{\circ} \mathrm{C}$ for $24 \mathrm{~h}$ (lysis stage). After this procedure the cell morphology changed, spheroplasts were obtained and cellular lysis was observed. Thus, a clone of P. pastoris was obtained, which undergoes autolysis after a cold-shock.
\end{abstract}

Keywords: Autolysis, Cold-shock promoter, Glucanase, Saccharomyces cerevisiae, Pichia pastoris, White biotechnology

\section{Introduction}

The development of recombinant proteins has become one of the fastest growing areas in biotechnological and pharmaceutical industries (Rader 2013; Tang and Zhao 2009; Wagner and Alper 2016). Every year, the Food and Drug Administration of the United States approves new biopharmaceutical products that cover a wide range of innovative products for health care. For instance, of the 18 products approved in 2012, eight were recombinant proteins, suggesting that the production of recombinant proteins with pharmaceutical use is an increasing commercial activity (Rader 2013). The methylotrophic yeast Pichia pastoris has been used widely as an expression system for recombinant protein production offering fast growth rates in low cost media, relatively fast expression times, high protein yields, ease of genetic manipulation

\footnotetext{
*Correspondence: rmarsch@cinvestav.mx

${ }^{1}$ Department of Biotechnology and Bioengineering, Cinvestav-IPN,

Av. Instituto Politécnico Nacional 2508, Col. San Pedro Zacatenco,

07360 Gustavo A. Madero, CDMX, Mexico

Full list of author information is available at the end of the article
}

and a post-translational processing system similar to that of Mammalia (Ahmad et al. 2014; Athmaram et al. 2013; Byrne 2015). The production of recombinant proteins includes commonly processing steps such as development and culture of the strain, extraction, purification and formulation of the recombinant protein (Looser et al. 2015; Wolf and Reichl 2011). The extraction and purification of a recombinant protein may contribute to $80 \%$ or more of the total production cost (Ahuja 2000). Accordingly, reducing the cost of the extraction and purification is of great economic importance. Cells have to be lysed often by drastic methods to recover intracellular proteins and this can affect the product and thus the yield (Garcia-Ortega et al. 2015). A major impediment to reduce production costs of recombinant proteins is the availability of a low-cost recovery technology that does not affect adversely the protein and/or the environment (Balasundaram et al. 2009). A low cost alternative with little or no environmental impact would be to use autolytic strains. In the wine making industry natural or genetically obtained autolytic Saccharomyces strains are used 
to improve wine quality and facilitate certain parts of the wine making process (Grossmann et al. 2011). Autolysis of Saccharomyces cells in this process depends on autophagy and degradation of cell constituents, including proteins (Alexandre and Guilloux-Benatier 2006; Cebollero et al. 2005; Cebollero and Gonzalez 2006; Grossmann et al. 2011). Since recombinant protein processes are intended to produce proteins, the above-mentioned strains cannot be used. A possible solution might be the use of enzymes that degrade yeast cell wall constituents, so that the cell wall becomes fragile, facilitating cell lysis, but avoiding protein degradation.

The inner layer of the yeast cell wall provides rigidity to the cell and consists of a glucan-net with small spots of chitin (Levin 2011). The glucan-net is formed by long chains of $\beta$-1,3-glucan with chain branches attached through $\beta-1,6$ linkages (Orlean 2012). Endo- $\beta-1,3-$ glucanases can degrade the glucan-net of $S$. cerevisiae cell wall (Baladrón et al. 2002; Ferrer et al. 1996; Tanaka and Phaff 1965) and they have been used to make the yeast cell wall fragile in certain production processes (Cheng et al. 2013). Moreover, eng from P. pastoris encodes for a secreted putative endo- $\beta-1,3$-glucanase (ENG; accession no. NC_012963) that may be suitable to make the cell wall fragile. In this work, the promoter Pccta from $S$. cerevisiae, i.e. a promoter induced by a cold-shock (AlFageeh and Smales 2006; Somer et al. 2002), was selected to control eng expression from $P$. pastoris. This promoter controls the expression of the alpha subunit of chaperonin-containing $\mathrm{T}$-complex $(\mathrm{CCT} \alpha)$ and it was shown previously that a cold-shock increases 3-4 times the expression of CCT $\alpha$ (Somer et al. 2002).

The aim of this work was to show that a transgenic strain of $P$. pastoris could undergo autolysis after induction by a cold-shock. The endogenous eng gene of $P$. pastoris was overexpressed under the control of the Pcct $\alpha$ promoter from S. cerevisiae. This promoter was induced by cold-shock, and it was shown that this weakens the yeast cell wall, promotes the formation of spheroplasts and induces cell lysis. This approach can be useful to facilitate the purification of recombinant proteins in industrial processes.

\section{Materials and methods \\ Biological materials}

References for the nucleotide sequences used in this work are given in Table 1. They were all amplified by PCR. The cold induced promoter of the alpha subunit of chaperonin-containing T-complex (Pccto, chromosome IV, accession number NC_001136, nt: 886842-887284) was amplified from S. cerevisiae S288C. The strain was obtained from the National Collection of Microbial Cultures (Cinvestav-IPN, Mexico). Pichia pastoris GS115 was purchased from Invitrogen (Carlsbad, CA, USA). This strain was used for the final strain construction as well as the source of the gene encoding for a putative endo- $\beta$-1,3-glucanase (chromosome 1, accession number NC_012963; GeneID: 8197918). The functional gene leu 2 encoding a $\beta$-isopropylmalate dehydrogenase $(\beta-\mathrm{IMDH})$ that catalyzes the third step in the leucine biosynthetic pathway (chromosome 3, accession number NC_012965; GeneID: 8199325) was also obtained from P. pastoris GS115. Pichia pastoris CL2 (deposition number CDBB-L-1984) was constructed in this work and deposited at the "Colección Nacional de Cepas Microbianas y Cultivos Celulares" Cinvestav-IPN (Mexico). The plasmid pGAPZ $\alpha$ A (Invitrogen) was used as the source to amplify the region aox 1 TT of the transcription terminator of aox 1 , a fragment containing the tefl promoter $\left(\mathrm{P}_{t e f \mathrm{I}}\right)$ from S. cerevisiae, the synthetic bacterial promoter of EM7 ( $\left.\mathrm{P}_{\mathrm{EM}}\right)$, the bleomycin resistance gene (ble) from Streptoalloteichus hindustanus and the transcription

Table 1 Sequences used in this study

\begin{tabular}{|c|c|c|c|c|}
\hline Sequence & Description & Source & Amplicon & Reference \\
\hline Pccta & $\begin{array}{l}\text { Alpha subunit promoter from cytoplasmic chaperonin } \\
\text { CCT }\end{array}$ & S. cerevisiae & YL1 & $\begin{array}{l}\text { Chromosome IV, Accession No. NC_001136, nt: } 886842- \\
887284\end{array}$ \\
\hline eng & Gene encoding a putative endo- $\beta$-1,3-glucanase & P.pastoris & YL2 & $\begin{array}{l}\text { Chromosome 1, Accession No. NC_012963; GenelD: } \\
\quad 8197918\end{array}$ \\
\hline $\operatorname{aox} 1 \mathrm{TT}$ & aox 1 transcription termination region & P.pastoris & YL3 & \multirow{5}{*}{$\begin{array}{l}\text { Online catalog. pGAPZa A, B, and C. Pichia expression } \\
\text { vectors for constitutive expression and purification of } \\
\text { recombinant proteins (Invitrogen, CA, USA) https:// } \\
\text { www.thermofisher.com/order/catalog/product/ } \\
\text { V20020 }\end{array}$} \\
\hline$P_{\text {tef1 }}$ & Eukaryotic constitutive promoter & S. cerevisiae & $Y L 4$ & \\
\hline$P_{\text {EM7 }}$ & Prokaryotic constitutive promoter & Synthetic & & \\
\hline ble & $\begin{array}{l}\text { Gene encoding a protein that confers resistance to } \\
\text { zeocin }\end{array}$ & $\begin{array}{l}\text { S. hindusta- } \\
\text { nus }\end{array}$ & & \\
\hline cyc1 ТТ & End $3^{\prime}$ of the gene $c y c 1$ for transcription termination & S. cerevisiae & & \\
\hline leu2 & $\begin{array}{l}\text { Functional gene of the } \beta \text {-isopropylmalate dehydroge- } \\
\text { nase (IMDH) }\end{array}$ & P.pastoris & YL5 & $\begin{array}{l}\text { Chromosome 3, Accession No. NC_012965; GenelD: } \\
\quad 8199325\end{array}$ \\
\hline
\end{tabular}


terminator of $c y c 1$ (cyc1 TT) from S. cerevisiae. Escherichia coli TOP10 was purchased from Invitrogen and used as plasmid host.

\section{Propagation of the strains and DNA isolation}

Saccharomyces cerevisiae was grown in YM medium (3 g malt extract, $5 \mathrm{~g}$ peptone, and $10 \mathrm{~g}$ glucose per liter), while $P$. pastoris was cultived in YPD medium ( $10 \mathrm{~g}$ yeast extract, $20 \mathrm{~g}$ peptone, $20 \mathrm{~g}$ dextrose per liter). The YM and YPD were supplemented with $15 \mathrm{~g}$ agar for the solid media. Genomic DNA from both P. pastoris and S. cerevisiae was extracted from cell cultures in the exponential growth phase, and purified using the Qiagen Dneasy ${ }^{\mathrm{TM}}$ Blood \& Tissue Kit (Valencia, CA, USA) according to the instructions of the manufacturer.

Escherichia coli was grown in LB medium (Sambrook and Russell 2001). Plasmid DNA was purified using a modification of the method of Birnboim and Doly (Sambrook and Russell 2001).

\section{Construction of plasmid pLGC09}

The plasmid pLGC09, derived from plasmid $\mathrm{pCR}^{\circledR} 4$ Blunt-TOPO $^{\circledR} \quad$ (Invitrogen), was constructed to provide $P$. pastoris with the putative endo- $\beta-1,3-$ glucanase under the control of Pcct $\alpha$ (Fig. 1). The plasmid construction was done using conventional techniques, i.e. $\mathrm{PCR}$, endonuclease restriction and ligation (Sambrook

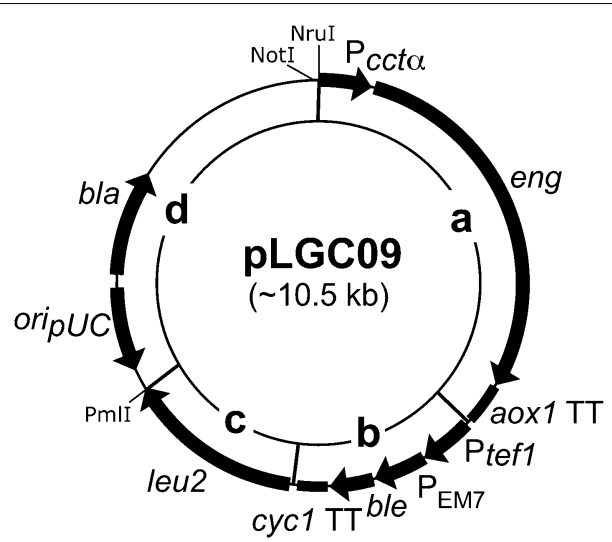

Fig. 1 Structure of pLGC09. Plasmid pLGC09 comprises three modules: a the lytic regulated module is composed of the promoter of chaperonin CCT one complex (Pccta) that drives expression of eng in P. pastoris and it is finished by aox 1 transcription termination (aox1 TT) region; $\mathbf{b}$ the selection marker module is composed of the translational elongation factor 1 gene promoter $\left(P_{\text {teff }}\right)$ and of the EM7 synthetic prokaryotic promoter $\left(P_{E M 7}\right)$ that drive expression of the ble gene in P. pastoris and E. coli respectively, these expressions are finished by cycl transcription termination region (cycl TT); c the homologous recombination module is composed of the leu2 functional gene including its promoter and transcription termination region; and $\mathbf{d}$ the replicon $\mathrm{pCR}{ }^{\circledR} 4 \mathrm{Blunt}-\mathrm{TOPO}{ }^{\circledR}$ that includes the functional gene bla and pUC origin (ori $i_{p u c}$ ) and Russell 2001). The restriction endonucleases used and T4 DNA ligase were purchased from New England Biolabs (Ipswich, MA, USA) and used according to the indications of the supplier. The primers used to amplify promoters, terminators, and genes are shown in Table 2. All primers were purchased from Sigma-Genosys (St. Louis, MO, USA). All PCRs were performed using Pfu DNA polymerase (Fermentas) in a Bio-Rad $\mathrm{T} 100^{\mathrm{TM}}$ Thermal Cycler (Hercules, CA, USA). All PCRs were done under the same conditions, i.e. initial denaturation at $95{ }^{\circ} \mathrm{C}$ during $5 \mathrm{~min}$ and 34 cycles comprising: denaturation at $95{ }^{\circ} \mathrm{C}$ for $30 \mathrm{~s}$ and annealing at $55^{\circ} \mathrm{C}$ for $40 \mathrm{~s}$. A 2 min extension was done per expected thousand base pairs amplicon and a final extension at $72{ }^{\circ} \mathrm{C}$ for $7 \mathrm{~min}$. All amplicons were verified by agarose electrophoresis and sequencing.

Three modules were obtained: First, to construct the lytic module, the promoter Pcct $\alpha$ amplified from the genomic DNA of S. cerevisiae (amplicon YL1; Table 2 shows the corresponding primers used to amplify each amplicon, i.e. YL1-F and YL1-R to amplify amplicon YL1), and the gene eng amplified from the genomic DNA of P. pastoris GS115 (amplicon YL2) were digested with $B a m \mathrm{HI}$ and BglII respectively. They were joined together through T4 DNA Ligase and PCR using primers YL1-F and YL2-R. The amplicon YL1-YL2 digested with XhoI and aox1 TT amplified from pGAPZ $\alpha$ A (Invitrogen; amplicon YL3) digested with SalI were ligated together (Table 2 shows the restriction sites used to construct the module, the joining of $B a m \mathrm{HI}$ to $B g l \mathrm{II}$ and $\mathrm{XhoI}$ to SalI digested ends are cohesives but their joining does not let the sites to be regenerated), and through PCR using primers YL1-F and YL3-R the lytic module was amplified. Second, the selection marker module consisted of a fragment containing the promoters $\mathrm{P}_{t e f 1}$ and $\mathrm{P}_{\mathrm{EM}}$, ble, and the cyc1 TT was directly amplified from pGAPZ $\alpha A$ (amplicon YL4). Third, the full-length leu2 gene including its promoter and transcription terminator was amplified from the genomic DNA of P. pastoris (amplicon YL5) to be the integration module. All modules were cloned each in pJET1.2/blunt using the Clone$\mathrm{JET}^{\mathrm{TM}}$ PCR Cloning Kit (Fermentas; Waltham, MA, USA) according to the instructions of the manufacturer. The plasmid containing the selection marker module was digested with PmlI, ligated to the plasmid including the integrative module digested with $\mathrm{NruI}$ (both enzymes produce blunt ends), and amplified through PCR using the primers YL4-F and YL5-R. The two-modules amplicon was cloned in $\mathrm{pCR}^{\circledR} 4 \mathrm{Blunt}-\mathrm{TOPO}{ }^{\circledR}$ using the Zero Blunt $^{\circledR}$ TOPO $^{\circledR}$ PCR Cloning Kit for Sequencing (Invitrogen) following the instructions of the supplier. The final construction was assembled in $\mathrm{PCR}^{\circledR} 4 \mathrm{Blunt}^{\circledR} \mathrm{TOPO}{ }^{\circledR}$ by subcloning the fragment NotI-PmlI from the 
Table 2 Primers used in this study

\begin{tabular}{|c|c|c|c|}
\hline Primer $^{a}$ & Sequence $\left(5^{\prime} \rightarrow 3^{\prime}\right)^{b}$ & Restriction enzyme & Underlined sequence $^{c}$ \\
\hline YL1-F & GGGGtcgcgaGAATCTTCCTCAGAAGAGGAAT & Nrul & $\begin{array}{l}\text { Homologous Pccta region corresponding to nucleotides (nt) } 886842 \\
\text { to } 886863\end{array}$ \\
\hline YL1-R & GCGCggatccTCACCTCCTAGGAAAAGGGTAT & $\mathrm{BamHI}$ & Homologous Pccta region corresponding to nt 887263 to 887284 \\
\hline YL2-F & CCCCagatctCCCAAATGTCATTCTCTTCCAA & $B g / l l$ & Homologous eng region corresponding to nt 802095 to 802116 \\
\hline YL2-R & GCGCctcgagITAAACGGAATTAGCCAGTCCT & Xhol & Homologous eng region corresponding to nt 805153 to 805132 \\
\hline YL3-F & GCGCgtcgacTGAGTTTTAGCCTTAGACATGACT & Sall & Homologous aox 1 TT region corresponding to nt 627 to 650 \\
\hline YL3-R & GGGGcacgtgCCGCACAAACGAAGGTCTCA & Pm/l & Homologous aox 1 TT region corresponding to nt 970 to 957 \\
\hline$Y\lfloor 4-F$ & GGGGatttaaatCCCACACACCATAGCTTCAAA & Swal & Homologous Ptef1 region corresponding to nt 971 to 993 \\
\hline YL4-R & GGGGcacgtgICTCCAGCTTGCAAATTAAAG & Pm/l & Homologous cyc 1 TT region corresponding to nt 2142 to 2122 \\
\hline YL5-F & GGGGtcgcgaGTATATTGAGGAGCAGAACTAG & Nrul & Homologous leu2 region corresponding to nt 86482 to 86503 \\
\hline YL5-R & GGGGcacgtgCTTTTTCCGAACCTTACAGTAG & Pm/l & Homologous leu2 region corresponding to nt 87943 to 87922 \\
\hline
\end{tabular}

${ }^{a}$ F forward primer, $R$ reverse primer

${ }^{b}$ Lowercase letters indicates the restriction endonuclease recognized site denoted in the next column

c Nucleotide numbering has been taken according to the sequence depicted in the access number mentioned in the section of materials and methods

plasmid including the lytic module in NotI-SwaI digested $\mathrm{pCR}^{\circledR} 4$ Blunt-TOPO ${ }^{\circledR}$-selection marker and integration modules using classical restriction and ligation techniques (Sambrook and Russell 2001), obtaining at last the vector pLGC09 (details on the construction strategy, and pLGC09 data could be consulted in Additional files 1, 2).

\section{Transformation of P. pastoris GS115 with pLGC09}

Pichia pastoris CL2 was obtained through transformation of electrocompetent cells of P. pastoris GS115 with pLGC09 as described by Higgins and Cregg (1998). A Bio-Rad MicroPulser ${ }^{\mathrm{TM}}$ (Hercules, CA, USA) was used to electroporate the cells in Sigma-Aldrich $0.2 \mathrm{~cm}$ gap width cuvettes (St. Louis, MO, USA). Conditions for $P$. pastoris electroporation were already programed in the apparatus ( $2.0 \mathrm{kV}, 1$ pulse, $4.5 \mathrm{~ms})$. Ten micrograms of pLGC09 were used for $80 \mu \mathrm{l}$ electrocompetent cells. The transformant clones were selected on YPDS agar (same as YPD, but added with $1 \mathrm{M}$ sorbitol) supplemented with zeocin $(500 \mu \mathrm{g} / \mathrm{ml}$; Invitrogen $)$, according to the manual included in the Invitrogen EasySelect ${ }^{\mathrm{TM}}$ Pichia Expression Kit.

\section{Effect of eng expression on cell morphology}

The cells were observed with a microscope to determine if the eng expression controlled by Pcct $\alpha$ and induced by cold-shock conditions had an effect on the cell wall and morphology of Pichia cells. The inocula of P. pastoris GS115 and P. pastoris CL2 were prepared in YPD medium $\left[50 \mathrm{ml}\right.$ in $250 \mathrm{ml}$-Erlenmeyer flasks, $30{ }^{\circ} \mathrm{C}$, $150 \mathrm{rpm}, 18 \mathrm{~h}$; in a TERLAB DBO incubator (El Arenal, Jal., Mexico) with orbital shaker]. The cells were harvested and washed once with sterile distilled water, centrifuged at $4000 \mathrm{rpm}$ and at room temperature for $10 \mathrm{~min}$ in a DuPont SORVALL SUPER-ST 21 centrifuge with SL 50T rotor (Wilmington, DE, USA). The treatments described below were applied on cells grown in BMGH medium ( $\mathrm{pH}$ 4.5; Invitrogen EasySelect ${ }^{\mathrm{TM}}$ Pichia Expression Kit manual) supplemented with 1/50 (v/v) of a solution containing $250 \mathrm{mM} \mathrm{MnSO}_{4}$ and $50 \mathrm{mM} \mathrm{MgSO}_{4}$. The cell pellets from centrifuged inocula were suspended in BMGH medium, adjusted to $\mathrm{OD}_{600}=1$ and $50 \mathrm{ml}$ of the suspension was poured into $250 \mathrm{ml}$-Erlenmeyer flasks. The cultures were incubated at $30{ }^{\circ} \mathrm{C}(150 \mathrm{rpm})$ for $4 \mathrm{~h}$. Cells were chilled to $4{ }^{\circ} \mathrm{C}$ for the cold-shock stage (stage I). A gene expression stage (stage II) was applied by incubating the cells at $4{ }^{\circ} \mathrm{C}(150 \mathrm{rpm})$ for $6 \mathrm{~h}$. The cells were incubated at $30^{\circ} \mathrm{C}(150 \mathrm{rpm})$ for $6 \mathrm{~h}$ (stage III) for ENG synthesis. Finally, the cells were incubated either 12 or $24 \mathrm{~h}(150 \mathrm{rpm})$ at $37^{\circ} \mathrm{C}$ (stage IV) for cell lysis. Cells subjected to the entire treatment (stages I-IV) were prepared for optical microscopy as follows: cells (following stage IV incubation) were collected from $1.0 \mathrm{ml}$ samples by centrifugation at $10,000 \mathrm{rpm}$ for $1.5 \mathrm{~min}$ in a Eppendorf Centrifuge 5424 (Hamburg, Germany). After centrifugation the cells were suspended in $1.0 \mathrm{ml}$ distilled water and mixed with Coomassie brilliant blue R-250 staining solution (5:1; Bio-Rad). The morphology of cells was determined with an OLYMPUS CX31 optical microscope (Shinjuku-ku, To., Japan) and the images were captured with a Sony Cyber-shot DSC-S930 digital camera (Minato-ku, To., Japan). Cell morphology was determined after $12 \mathrm{~h}$ in stage IV by scanning electron microscopy (SEM). Cells were sputter coated with gold and analysed by using the microscopy service of the "Laboratorio Avanzado de Nanoscopía Electrónica" (LANE) Cinvestav-IPN (Mexico), using a FE HRSEM-Auriga 3916 Zeiss Microscope (Oberkochen, Baden-Wurtemberg, 
Germany) at an accelerating voltage of $2 \mathrm{kV}$. P. pastoris GS115 cells served as control in the experiments and were treated in the same way as P. pastoris CL2 cells.

\section{Quantification of eng expression}

To determine the eng expression, mRNA was quantified with a quantitative reverse transcription polymerase chain reaction (qRT-PCR) with an Applied Biosystems 7500 Fast Real-Time PCR System (Foster City, CA, USA). Total RNA was extracted in triplicate from culture broth samples $(1 \mathrm{ml})$ of $P$. pastoris GS115 and P. pastoris CL2 collected at 0,2 and $6 \mathrm{~h}$ during stage II; and $2 \mathrm{~h}$ during stage III. Cells from culture broth samples were washed with sterile distilled water as described in the previous section (except that the first and fourth samples were washed at room temperature, while the second and third samples were washed at $4{ }^{\circ} \mathrm{C}$ ). The cell pellets were lyophilized and kept at $-70{ }^{\circ} \mathrm{C}$ until used. Cell lysis was accomplished by three freezing cycles with liquid nitrogen and macerated with a polypropylene pestle $(1 \mathrm{~min}$ each). Total RNA was extracted with the Trizol ${ }^{\mathrm{TM}}$ Reagent (Invitrogen) method following the instructions of the supplier. Total RNA samples were treated with DNase I (Invitrogen) to remove DNA. The first DNA strand of cDNA encoding ENG was synthesized by reverse transcription from $1 \mu \mathrm{g}$ total RNA using the Super Script III Reverse Transcriptase System Kit (Invitrogen).

Primers and probes used for qRT-PCR analyses were designed by Applied Biosystems (Foster City, CA, USA; Table 3). The qRT-PCR analyses were done with a 7500 Fast Real-Time PCR System of Applied Biosystems using TaqMan ${ }^{\circledR}$ Gene Expression Master Mix 2X (Foster City, CA, USA) with a total reaction volume of $10 \mu \mathrm{l}$. FAM fluorophore was used to detect both act1 (housekeeping

\section{Table 3 Real-time PCR primers and probes used in this} study

\begin{tabular}{|c|c|c|}
\hline Primer or probe $^{a}$ & Sequence $\left(5^{\prime}-3^{\prime}\right)$ & Modification $^{b}$ \\
\hline \multicolumn{3}{|l|}{ Primer } \\
\hline eng-F (TaqMan MGB) & GTCGGTTGACGGGTTAATTGTG & None \\
\hline eng-R (TaqMan MGB) & AGCCGCATAGTCGTAGTAAATCA & None \\
\hline act1-F (TaqMan MGB) & TGTCTGAGCGTGGTTACACTTTT & None \\
\hline act7-R (TaqMan MGB) & $\begin{array}{l}\text { CAACGTAACAAAGCTTCTCCT } \\
\text { TGAT }\end{array}$ & None \\
\hline \multicolumn{3}{|l|}{ Probe } \\
\hline eng (TaqMan ${ }^{\circledR}$ probe) & CTGCCTTGGCAACTTG & FAM/MGB-NFQ \\
\hline $\operatorname{act1}\left(\right.$ TaqMan ${ }^{\circledR}$ probe) & CACGGACGATTTCTCT & FAM/MGB-NFQ \\
\hline \multicolumn{3}{|c|}{$\begin{array}{l}\text { FAM fluorophore 6-carboxyfluorescein, MGB minor groove binder, NFQ } \\
\text { nonfluorescent quencher }\end{array}$} \\
\hline
\end{tabular}

gene control) and eng. Amplification conditions for qRTPCR were as follows: $50{ }^{\circ} \mathrm{C}$ for $2 \mathrm{~min}, 95^{\circ} \mathrm{C}$ for $10 \mathrm{~min}$, 40 cycles of $95{ }^{\circ} \mathrm{C}$ for $15 \mathrm{~s}$ followed by $60^{\circ} \mathrm{C}$ for $1 \mathrm{~min}$. All reactions were performed in triplicate on each plate with three independent replicates, and gene expression values were calculated using the difference in eng expression relative to act 1 expression using the method $2^{-\Delta \Delta \mathrm{Ct}}$ (Livak and Schmittgen 2001).

\section{Results \\ Effect of eng expression on cell morphology}

After the transformation of $P$. pastoris GS115 with pLGC09, transgenic $P$. pastoris CL2 was selected among six zeocin resistant colonies. In addition, P. pastoris CL2 strain was the most resistant to the antibiotic, the most sensitive to cold-shock induction and showed the most aberrant cell morphology as determined by optical microscopy with Coomasie brilliant blue staining. Figure 2 shows $P$. pastoris CL2 cells, 12 and $24 \mathrm{~h}$ after a treatment consisting of the cold-shock (stage I), gene expression (stage II), ENG synthesis (stage III) and lysis (stage IV). Pichia pastoris GS115 was used as control. The cells of $P$. pastoris CL2 increased in size and became irregular after $12 \mathrm{~h}$ in stage IV. Some cells were stained with Coomasie brilliant blue, and cellular debris were also stained with the dye (Fig. 2b). Twenty-four hours after the treatment, most cells were lysed and those that were not broken were irregular and enlarged. The latter were stained and cellular debris was noticed clearly (Fig. 2d). Contrarily, the P. pastoris GS115 cells were not affected noticeably by the treatment (Fig. 2a, c). The morphology of each cell type was also examined before applying the entire treatment, but no differences were found in morphology or fragility, between the P. pastoris GS115 cells and P. pastoris CL2 cells (data not shown).

Additionally, Pichia pastoris GS115 cells and transformed cells of $P$. pastoris CL2, both subjected to the entire treatment were prepared $(12 \mathrm{~h}$ incubation on stage IV) and observed by SEM. The Pichia pastoris GS115 control cells had an average size ranging from 2 to $3 \mu \mathrm{m}$ (Fig. 3a), whereas P. pastoris CL2 cells formed spheroplasts larger than $10 \mu \mathrm{m}$ (Fig. 3b).

\section{Quantification of eng expression}

qRT-PCR analyses were done to determine the expression of eng induced in P. pastoris CL2. Figure 4 shows the relative expression of eng in $P$. pastoris CL2 at different stages of treatment as compared with eng expression in P. pastoris GS115 under the same conditions. The relative expression of the eng within stage II was 1.6 fold higher at $4{ }^{\circ} \mathrm{C}$ after $2 \mathrm{~h}$ and 4.6 fold after $6 \mathrm{~h}$. During the stage III (at $30{ }^{\circ} \mathrm{C}$ for $2 \mathrm{~h}$ ), the relative expression of eng was lower, i.e. 0.74 times. 

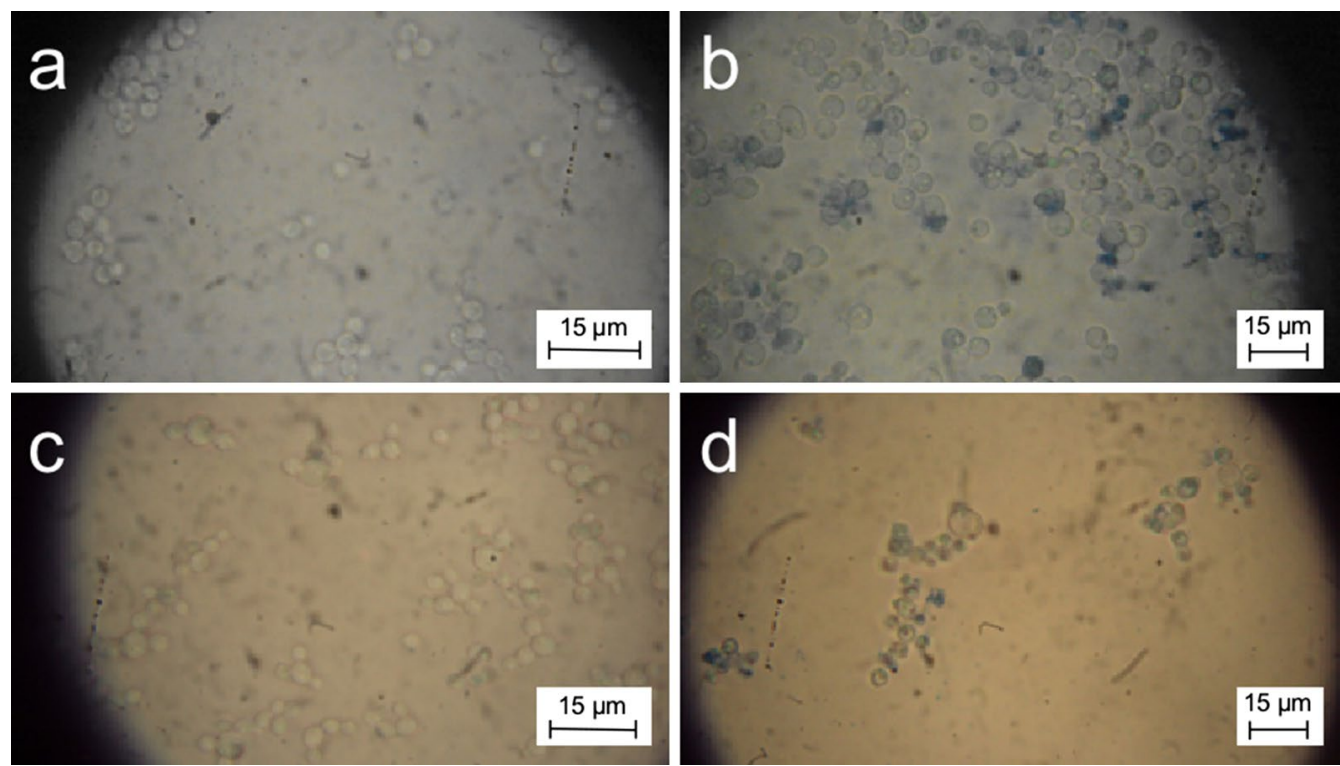

Fig. 2 Analysis by optical microscopy (100x) after staining with Coomassie blue R-250 of Pichia pastoris GS115 (control) and P.pastoris CL2 cells induced by cold-shock and after the entire treatment. a, c Control cells of P. pastoris GS115 at $12 \mathrm{~h}$ and $24 \mathrm{~h}$ in stage IV, respectivelly; $\mathbf{b}$, d $P$. pastoris CL2 cells at 12 and $24 \mathrm{~h}$ in stage IV, respectively. Bar $15 \mu \mathrm{m}$
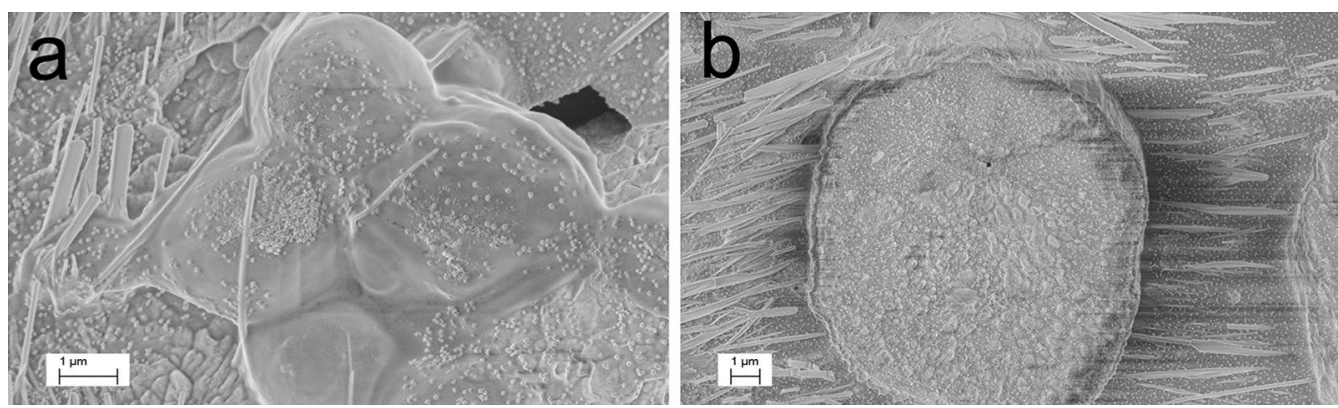

Fig. 3 Analysis by scanning electron microscopy (SEM) of Pichia pastoris GS1 15 (control) and P. pastoris CL2 cells induced by cold-shock and after the entire treatment. a Control cells of P. pastoris GS1 15 at $12 \mathrm{~h}$ in stage IV. b P. pastoris CL2 at 12 h during stage IV. In both photographs phosphate salt crystals are observed surrounding cells. Bar $1 \mu \mathrm{m}$

\section{Discussion}

The biotechnological and pharmaceutical industries are fast-growing (Rader 2013; Tang and Zhao 2009). In particular, substantial resources are applied to the development of recombinant protein production with $P$. pastoris (Calik et al. 2015), the most widely used system as expression system for heterologous protein production (Gasser et al. 2013). Purification of recombinant proteins, including cell lysis is commonly recognized among the most costly parts of entire production processes (Ernst et al. 1997). Additionally, the cells are disrupted frequently under harsh conditions that can affect the product quality. A low cost process for cell lysis that does not compromise protein quality or the environment would be desirable. Autolysis of P. pastoris induced at low temperature could be such a technique.

The recovery of an intracellular recombinant protein depends on breaking the cell wall at the end of yeast growth. The inner layer of the cell wall of $S$. cerevisiae is formed by glucanes with $\beta-1,3$ and $\beta-1,6$ glycosidic bonds and chitin (Levin 2011). In Pichia the glucanes: chitin ratio varies from 75:25 to 95:5 depending on growth conditions (Chagas et al. 2014; Farinha et al. 2015). Glucanes form a net that is responsible for the rigidity and shape of yeast cells (Levin 2011). An enzyme degrading glucanes would weaken the yeast cell wall and compromise 


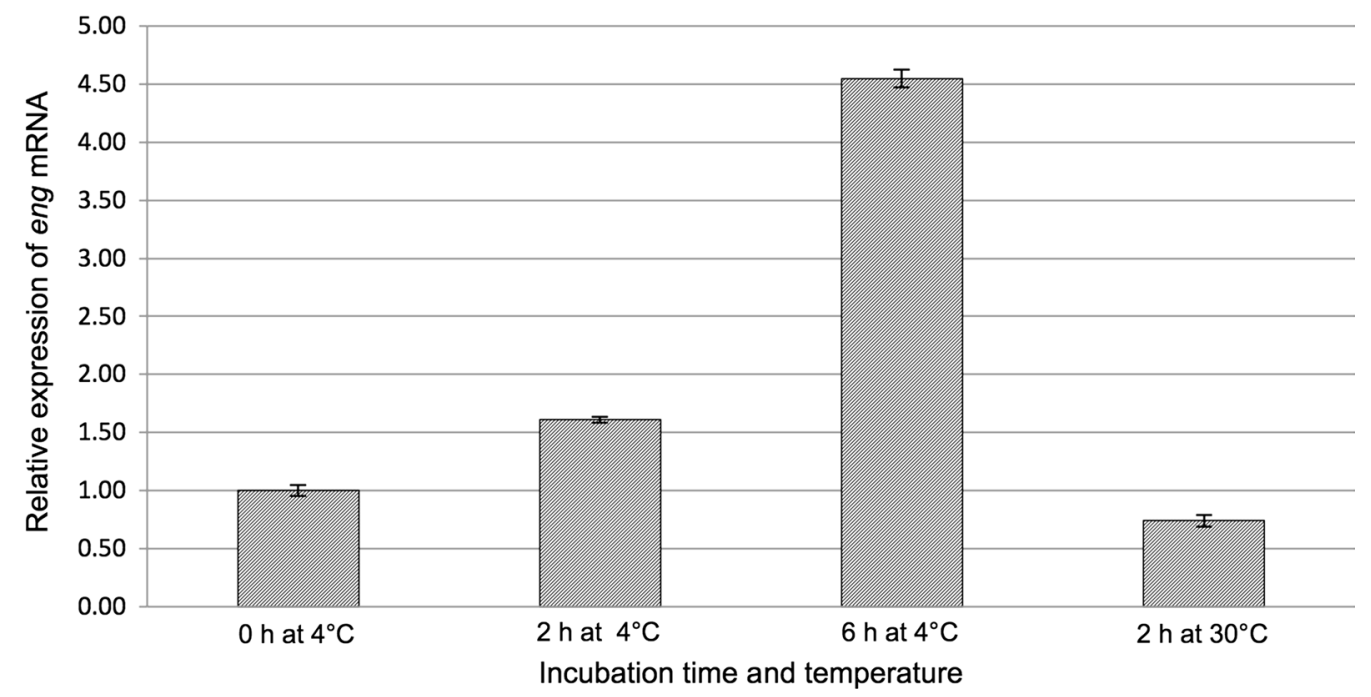

Fig. 4 Relative expression of eng mRNA in P. pastoris $C L 2$ in response to cold-shock at $4{ }^{\circ} \mathrm{C}$. CL2 cells were grown in medium $B M G H\left(30^{\circ} \mathrm{C}\right.$ for $4 \mathrm{~h}$ ), from $\mathrm{OD}_{600}=1$ inoculum, then subjected to cold-shock for the induction of eng mRNA transcript expression $\left(4^{\circ} \mathrm{C}\right.$ for $\left.6 \mathrm{~h}\right)$. Samples were taken at 0,2 and $6 \mathrm{~h}$ for analysis by qRT-PCR; and finally, they were transferred to $30^{\circ} \mathrm{C}$ for $4 \mathrm{~h}$ for ENG product synthesis, stage in which the corresponding sample at $2 \mathrm{~h}$ was taken for analysis by qRT-PCR. The values of relative expression of eng mRNA were calculated in relation to eng and the housekeeping constitutive gene actl (control) expression using method $2^{-\Delta \Delta C t}$

the cell integrity. Tanaka and Phaff (1965) found that $\beta$-glucanases from Bacillus circulans are able to degrade baker's yeast cell wall and that $\beta$-1,3-glucanase was more effective than the $\beta-1,6$-glucanase. Moreover, yeasts possess glucanase encoding genes within their genomes, for these enzymes are needed to restructure the cell wall and to separate the budding cells from the mother cell (Baladrón et al. 2002; Martín-Cuadrado et al. 2003). P. pastoris has an eng gene encoding a putative endo- $\beta-1,3-$ glucanase homologous to eng1 from $S$. cerevisiae (Baladrón et al. 2002). In the present work, this endogenous eng gene was selected to show that its overexpression in $P$. pastoris induces cell wall degradation, causing cell fragility as well as cell lysis.

Somer et al. (2002) found that the expression of Pcct $\alpha$ of $S$. cerevisiae cells under cold-shock conditions increased three to four times. In P. pastoris CL2, the expression of eng was 3.6 times higher under cold-shock conditions than in absence of the induction process. This proved that Pccto was functional in P. pastoris CL2 as it is in its natural genetic environment (S. cerevisiae). The return to warmer conditions after the cold-shock decreased rapidly the amount of the RNA transcripted under Pccta control suggesting a rapid degradation of eng mRNA in this system. Somer et al. (2002) obtained similar results in their study.

To our knowledge, cold-shock promoters are not used yet in yeasts intended for industrial use. However, these promoters are already used in prokaryotes, especially in
E. coli. The most often used cold-shock vector includes the promoter of the $E$. coli endogenous gene $\operatorname{csp} A$, which is suitable for induction of cloned genes by means of cold-shock. The promoter is used mainly to express proteins that are toxic to the host, or for highly unstable systems at $37{ }^{\circ} \mathrm{C}$ (Mujacic et al. 1999) to confer higher solubility and stability to expressed proteins (Qing et al. 2004).

After the entire treatment transgenic P. pastoris CL2 cells were irregular and ranged in size from similar to 3.3 times larger than the control cells. This appears to be due to the loss of the glucanes-net integrity resulting in spheroplasts. Coomasie blue staining showed that $P$. pastoris CL2 cells became permeable to the dye, but staining was absent in the control cells. This also indicated a loss of cell wall integrity. In P. pastoris CL2, the amount of cell debris increased after the entire treatment compared to the untreated control cells suggesting that the treated cells became fragile and were easily broken up. In fact, the treated cells could not be washed, as they had become too fragile and were broken up. Scan-electronic microscopy confirmed that spheroplasts of $P$. pastoris CL2 cells were bigger ( $\sim 10 \mu \mathrm{m}$ diameter) than the control cells $(\sim 3 \mu$ m diameter).

In this work it was shown that a transgenic strain of $P$. pastoris was constructed, which is able to undergo autolysis upon induction by cold-shock. The Pcct $\alpha$ cold-shock promoter from $S$. cerevisiae is functional in the genetic expression system of $P$. pastoris. The overexpression of 
the endogenous eng gene of $P$. pastoris leads to cellular fragility and autolysis. This work proves that the P. pastoris eng gene integrated to a suitable yeast expression system including the $S$. cerevisiae Pcct $\alpha$ can be used to develop an innovative inducible autolysis system by coldshock. This approach might be compatible with clean technologies, and with further development of particular applications might be a way to improve production processes for recombinant proteins, enzymes and pharmaceutical products avoiding mechanical or chemical cell lysis. Other stronger cold-shock promoters and enzymes with higher lytic activity could be studied to increase the effectiveness of the autolytic system.

\section{Additional files}

Additional file 1. Construction strategy of pLGC09.

Additional file 2. Plasmid pLGC09.

\begin{abstract}
Abbreviations
ENG: putative endo- $\beta-1,3$-glucanase; eng: gene encoding a putative endo- $\beta$ 1,3-glucanase; ccta: gene encoding alpha subunit from cytoplasmic chaperonin CCT: CCTa: alpha subunit from CCT: Pccta: promoter of the alpha subunit of CCT; ble: zeocin resistance gene; ori ${ }_{p u c}$ pUC replication origin; leu2: functional gene encoding $\beta$-isopropylmalate dehydrogenase; $P_{\text {tef } 1}$ : translational elongation factor 1 gene promoter; $\mathrm{P}_{\mathrm{EM}}$; synthetic prokaryotic promoter; $a 0 \times 1$ TT: aox 1 transcription termination region; сyc 1 TT: cyc1 transcription termination region.
\end{abstract}

\section{Authors' contributions}

YB-A and RM conceived the project, designed the experiments, interpreted results, wrote the manuscript and supervised participants. LD and LBF-C edited the manuscript. YB-A and CCh-C performed experiments. RM, LD and $\mathrm{LBF}-\mathrm{C}$ provided reagents and equipment. LD, LBF-C, MEH-L and MLV-T supervised the whole project development and analyzed results. All authors contributed in the final approval of manuscript. All authors read and approved the final manuscript.

\section{Author details}

1 Department of Biotechnology and Bioengineering, Cinvestav-IPN, Av. Instituto Politécnico Nacional 2508, Col. San Pedro Zacatenco, 07360 Gustavo A. Madero, CDMX, Mexico. ${ }^{2}$ Department of Microbiology, Escuela Nacional de Ciencias Biológicas del IPN, Prol. Carpio y Plan de Ayala S/N Col. Santo Tomás, 11340 Miguel Hidalgo, CDMX, Mexico.

\section{Acknowledgements}

We thank Josué Romero Ibarra (LANE-HRSEM, Cinvestav-IPN) for technical assistance.

\section{Competing interests}

The authors declare that they have no competing interests.

\section{Availability of data and materials}

We conducted experiments and data were generated. All data is shown in Figures and Tables within the article, and Additional files. An outline of the strategy to construct pLGC09 is provided in the Additional file 1, and pLGC09 data in the Additional file 2. Both as files in the software Gene Construction Kit (version 3.5.2) format.

\section{Ethics approval and consent to participate}

Not applicable. This article does not contain any studies with human participants or animals performed by any of the authors.

\section{Funding}

This research was funded by Cinvestav-IPN (Mexico) and "Consejo Nacional de Ciencia y Tecnología (Conacyt) Mexico" for grant-aided support to YB-A (Grant Number 46565)

\section{Publisher's Note}

Springer Nature remains neutral with regard to jurisdictional claims in published maps and institutional affiliations.

Received: 11 November 2016 Accepted: 2 May 2017

Published online: 12 May 2017

\section{References}

Ahmad M, Hirz M, Pichler H, Schwab H (2014) Protein expression in Pichia pastoris: recent achievements and perspectives for heterologous protein production. Appl Microbiol Biotechnol 98:5301-5317. doi:10.1007/ s00253-014-5732-5

Ahuja S (2000) Handbook of bioseparations: separation science and technology. Academic press, San Diego

Alexandre H, Guilloux-Benatier M (2006) Yeast autolysis in sparkling wine-a review. Aust J Grape Wine Res 12:119-127

Al-Fageeh MB, Smales CM (2006) Control and regulation of the cellular responses to cold shock: the responses in yeast and mammalian systems. Biochem J 397:247-259. doi:10.1042/BJ20060166

Athmaram TN, Singh AK, Saraswat S, Srivastava S, Misra P, Kameswara Rao M, Gopalan N, Rao PV (2013) A simple Pichia pastoris fermentation and downstream processing strategy for making recombinant pandemic swine origin influenza a virus hemagglutinin protein. J Ind Microbiol Biotechnol 40:245-255. doi:10.1007/s10295-012-1220-z

Baladrón V, Ufano S, Dueñas E, Martín-Cuadrado AB, del Rey F, Vázquez de Aldana CR (2002) Eng1 p, an endo-1,3- $\beta$-glucanase localized at the daughter side of the septum, is involved in cell separation in Saccharomyces cerevisiae. Eukaryot Cell 1:774-786. doi:10.1128/EC.1.5.774-786.2002

Balasundaram B, Harrison S, Bracewell DG (2009) Advances in product release strategies and impact in bioprocess design. Trends Biotechnol 27:477-485. doi:10.1016/j.tibtech.2009.04.004

Byrne B (2015) Pichia pastoris as an expression host for membrane protein structural biology. Curr Opin Struct Biol 32:9-17. doi:10.1016/j. sbi.2015.01.005

Calik P, Ata O, Gunes H, Massahi A, Boy E, Keskin A, Ozturk S, Zerze GH, Ozdamar TH (2015) Recombinant protein production in Pichia pastoris under glyceraldehyde-3-phosphate dehydrogenase promoter: from carbon source metabolism to bioreactor operation parameters. Biochem Eng J 95:20-36. doi:10.1016/j.bej.2014.12.003

Cebollero E, Gonzalez R (2006) Induction of autophagy by second-fermentation yeasts during elaboration of sparkling wines. Appl Environ Microbiol 72:4121-4127. doi:10.1128/AEM.02920-05

Cebollero E, Martinez-Rodriguez A, Carrascosa AV, Gonzalez R (2005) Overexpression of csc1-1. A plausible strategy to obtain wine yeast strains undergoing accelerated autolysis. FEMS Microbiol Lett 246:1-9. doi:10.1016/j. femsle.2005.03.030

Chagas B, Farinha I, Galinha CF, Freitas F, Reis MA (2014) Chitin-glucan complex production by Komagataella (Pichia) pastoris: impact of cultivation $\mathrm{pH}$ and temperature on polymer content and composition. N Biotechnol 31:468-474

Cheng R, Chen J, Yu X, Wang Y, Wang S, Zhang J (2013) Recombinant production and characterization of full-length and truncated $\beta-1,3-$ glucanase PglA from Paenibacillus sp. S09. BMC Biotechnol 13:105. doi:10.1186/1472-6750-13-105

Ernst S, Garro OA, Winkler S, Venkataraman G, Langer R, Cooney CL, Sasisekharan R (1997) Process simulation for recombinant protein production: cost estimation and sensitivity analysis for heparinase I expressed in Escherichia coli. Biotechnol Bioeng 53:575-582. doi:10.1002/ (SICI) 1097-0290(19970320)53:6<575:AID-BIT5>3.0.CO;2-J

Farinha I, Duarte P, Pimentel A, Plotnikova E, Chagas B, Mafra L, Grandfils C, Freitas F, Fortunato E, Reis MA (2015) Chitin-glucan complex production by Komagataella pastoris: downstream optimization and 
product characterization. Carbohydr Polym 130:455-464. doi:10.1016/j. carbpol.2015.05.034

Ferrer P, Hedegaard L, Halkier T, Diers I, Savva D, Asenjo JA (1996) Molecular cloning of a lytic $\beta-1,3$-glucanase gene from Oerskovia xanthineolytica LLG109. A beta-1,3-glucanase able to selectively permeabilize the yeast cell wall. Ann NY Acad Sci 782:555-565

Garcia-Ortega X, Reyes C, Montesinos JL, Valero F (2015) Overall key performance indicador to optimizing operation of high-pressure homogenizers for a reliable quantification of intracellular components in Pichia pastoris. Front Bioeng Biotechnol 3:107. doi:10.3389/fbioe.2015.00107

Gasser B, Prielhofer R, Marx H, Maurer M, Nocon J, Steiger M, Puxbaum V, Sauer M, Mattanovich D (2013) Pichia pastoris: protein production host and model organism for biomedical research. Future Microbiol 8:191-208. doi:10.2217/fmb.12.133

Grossmann M, Kiessling F, Singer J, Schoeman H, Schröder MB, von Wallbrun C (2011) Genetically modified wine yeasts and risk assessment studies covering different steps within the wine making process. Ann Microbiol 61:103-115. doi:10.1007/s13213-010-0088-2

Higgins DR, Cregg JM (1998) Pichia protocols: methods in molecular biology. Humana Press, New Jersey

Levin DE (2011) Regulation of cell wall biogenesis in Saccharomyces cerevisiae: the cell wall integrity signaling pathway. Genetics 189:1145-1175. doi:10.1534/genetics.111.128264

Livak KJ, Schmittgen TD (2001) Analysis of relative gene expression data using real-time quantitative PCR and the 2(-Delta Delta C(T)) method. Methods 25:402-408. doi:10.1006/meth.2001.1262

Looser V, Bruhlmann B, Bumbak F, Stenger C, Costa M, Camattari A, Fotiadis D, Kovar K (2015) Cultivation strategies to enhance productivity of Pichia pastoris: a review. Biotechnol Adv 33:1177-1193. doi:10.1016/j. biotechadv.2015.05.008

Martín-Cuadrado AB, Dueñas E, Sipiczki M, Vázquez de Aldana CR, del Rey F (2003) The endo- $\beta$-1,3-glucanase eng $1 p$ is required for dissolution of the primary septum during cell separation in Schizosaccharomyces pombe. J Cell Sci 116:1689-1698. doi:10.1242/jcs.00377
Mujacic M, Cooper KW, Baneyx F (1999) Cold-inducible cloning vectors for low-temperature protein expression in Escherichia coli: application to the production of a toxic and proteolytically sensitive fusion protein. Gene 238:325-332

Orlean P (2012) Architecture and biosynthesis of the Saccharomyces cerevisiae cell wall. Genetics 192:775-818. doi:10.1534/genetics.112.144485

Qing G, Ma LC, Khorchid A, Swapna GV, Mal TK, Takayama MM, Xia B, Phadtare S, Ke H, Acton T, Montelione GT, Ikura M, Inouye M (2004) Cold-shock induced high-yield protein production in Escherichia coli. Nat Biotechnol 22:877-882. doi:10.1038/nbt984

Rader RA (2013) FDA biopharmaceutical product approvals and trends in 2012. BioProcess Int 11:18-27

Sambrook J, Russell DW (2001) Molecular cloning: a laboratory manual. Cold Spring Harbor press, New York

Somer L, Shmulman O, Dror T, Hashmueli S, Kashi Y (2002) The eukaryote chaperonin CCT is a cold shock protein in Saccharomyces cerevisiae. Cell Stress Chaperones 7:47-54

Tanaka H, Phaff HJ (1965) Enzymatic hydrolysis of yeast cell walls. I. Isolation of wall-decomposing organisms and separation and purification of lytic enzymes. J Bacteriol 80:1570-1580

Tang WL, Zhao H (2009) Industrial biotechnology: tools and applications. Biotechnol J 4:1725-1739. doi:10.1002/biot.200900127

Wagner JM, Alper HS (2016) Synthetic biology and molecular genetics in nonconventional yeasts: current tools and future advances. Fungal Genet Biol 89:126-136. doi:10.1016/j.fgb.2015.12.001

Wolf MW, Reichl U (2011) Downstream processing of cell culture-derived virus particles. Expert Rev Vaccines 10:1451-1475. doi:10.1586/erv.11.111

\section{Submit your manuscript to a SpringerOpen ${ }^{\circ}$ journal and benefit from:}

- Convenient online submission

- Rigorous peer review

- Immediate publication on acceptance

- Open access: articles freely available online

- High visibility within the field

- Retaining the copyright to your article

Submit your next manuscript at $\boldsymbol{\nabla}$ springeropen.com 